\title{
THE FPC AND INDEFINITE PRICE ESCALATION CLAUSES: REMEDY FOR ADMINISTRATIVE BREAKDOWN
}

IN regulating the natural gas industry, the Federal Power Commission (FPC) has been faced in recent years with a backlog of business so great that effective regulation has been difficult. The genesis of this backlog lies in the 1954 holding of the Supreme Court in Phillips Petroleum Co. v. Wisconsin ${ }^{1}$ that under the Natural Gas Act of $1938^{2}$ the FPC must regulate natural gas sales between independent producers and interstate pipelines. ${ }^{3}$ Prior to that decision, the FPC, asserting a lack of authority to regulate sales by producers, had only regulated sales between the pipelines and distributing companies. ${ }^{4}$ During the period preceding Phillips the agency had handled an annual average of only $\$ 00$ filings for changes in rates and 150 applications for certificates of public convenience and necessity, which are required under the act before new service can be offered to the public and before existing facilities can be extended. ${ }^{5}$ Between June 7, 1954, and June 30, 1956, however, the Commission averaged over ten times as many rate change filings per year and over twenty-three times as many applications for certificates as it had in the previous period. ${ }^{6}$ Although the Commission's staff was augmented in 1958 , the situation has not improved. ${ }^{7}$ In a moment of despair, the FPC declared

1. 347 U.S. 672 (1954).

2. 52 Stat. 821 (1938), as amended, 15 U.S.C. $\S \S 717-717(w)$ (1958).

3. Independent producers are companies engaged in recovery of natural gas from its natural state and the sale of the gas to interstate pipelines. However, to be classified as "independent," these producers cannot at the same time engage in interstate transportation. Interstate pipelines, of course, build and maintain interstate transportation facilities. At times they possess extensive producing fields of their own. Local distributing companies purchase gas from the pipelines and sell it to the consumers. For purposes of regulation of interstate sales and transportation, one need not introduce the factor of intrastate pipeline companies or producers who do not sell interstate, especially since these represent only a small segment of the total industry. See MacAvoy, Price Formation in Natural Gas Fields 1-10 (1962).

4. In the matter of Columbian Fuel Corp., 2 FPC 200 (1940). The FPC relied upon $\S 1$ (b) of the Natural Gas Act, which provides authority over "sale in interstate commerce of natural gas for resale" but exempts from regulation "production or gathering of natural gas." 52 Stat. 821 (1938), 15 U.S.C. $\$ 717$ (b) (1958). The FPC interpreted these passages as meaning that it could regulate the affairs of companies actually engaged in interstate transportation by pipeline, but that it could not regulate contracts between those pipelines and independent producers of natural gas, as they were exempted as part of the independent "production" process.

5. 36 FPC ANN. Rep. 1 (1956).

6. Ibid. At the end of the 1956 fiscal year, there were still pending 2,980 certificate applications and 199 rate filings.

7. At the end of fiscal 1962 the Commission was faced with a burden of 728 pending producer rate filings and 2,355 producer certificate applications in addition to 269 pipeIne certificate applications and 97 pipeline rate filings. 42 FPC ANN. REP. 95, 96, 104, 105 (1962). 
in 1960 that even if its staff were tripled, it could not become current until the year 2043.8 Dean Landis in his 1961 report to President Kennedy on regulatory agencies cited the FPC as a classic example of administrative breakdown, ${ }^{9}$ and the Supreme Court has very recently taken notice of the Commission's backlog. ${ }^{10}$

The breakdown can be ascribed to a combination of the sheer number of producer rate filings and the complexity of the hearing on each application. The Commission has utilized a method for rate regulation which requires it to determine the cost basis of each regulated entity. ${ }^{11}$ As long as pipelines were the prime targets of regulation, this was at least a relatively workable method. The advent of producer regulation, however, has placed a burden on the system that it seems unable to assume. In the first place, computing the cost basis of a single pipeline is less complex than the computation for a

8. Phillips Petroleum Co., 24 F.P.C. 537, 546 (1960).

9. Staff of Subcomar. on Administrative Practice and Procedure, Senate Comm. on the Judictary, 86ri Cong., 2D Sess., Report on Regulatory Agencies to the Prestoent-Elect 54 (Comm. Print 1960). Some critics have asserted that the cause of the backlog is either gross negligence on the part of the Commission or resistance to the mandate of the Supreme Court in Phillips. On June 7, 1961, Congressman Yates made this statement:

There is one agency I think deserves a particular censure for its failure to assume its responsibility to the public. I refer to the Federal Power Commission; this Commission has been a slacker.

107 CoNG. Rec. 9665 (1961).

The CATCO controversy raised further doubts of Commission responsibility and independence. In this case the Commission, in a $\$ 7$ certificate proceeding, attached a condition imposing a lower rate than that requested by the producers. When the producers asserted that they would not accept the condition and applied pressure to the Commission including a threat to withdraw the gas from the interstate market, the agency capitulated and removed the condition. Continental Oil Co. (CATCO), 17 F.P.C. 880, 881 (1957). This action prompted a strong dissent by Commissioner Connole:

As concerned as I am for Tennessee's customers, I am more concerned for the whole body of consumers on all transmission pipelines for whose protection we are responsible. And as deserving of preservation as I believe these particular Orders to be, I believe the principle that Federal regulatory Orders should not be changed by threats of abandoning public responsibility is even more important. . . .

Id. at 886. The Commission's action was reversed by the Supreme Court. Atlantic Ref. Co. v. Public Serv. Comm'n (CATCO), 360 U.S. 378 (1959).

10. FPC v. Funt, 84 Sup. Ct. 861,868 (1964); and FPC v. Texaco, Inc., 84 Sup. Ct. 1105,1112 (1964).

11. FPC v. Hope Natural Gas Co., 320 U.S. 591 (1944), reiterated the principle of administrative law that regulation must provide the regulated company with a fair rate of returrm on its investment. Various methods of determining the cost basis for purposes of calculating fair return are, of course, possible, but City of Detroit v. FPC, 230 F.2d 810 (D.C. Cir. 1956), cert. denied, 352 U.S. 829 (1956) asserts the necessity of a full investigation of the financial situation of a company in each rate change hearing. Thus, under City of Detroit, the agency cannot use the much simpler method of assuming that the prevailing market price in the area or the price determined by arm's length bargaining will provide a fair return until proof to the contrary has been adduced. 
single producer. ${ }^{12}$ Secondly, there are far fewer pipeline companies than independent producers, as each pipeline delivers gas from a number of independent sources. Although each pipeline may distribute gas to a number of cities and, in theory, could show a different cost basis for each, Commission and pipeline practice has been to group distribution points into geographic blocks, within which a uniform tariff is charged. ${ }^{13}$ This practice reduces the number of hearings to be held if a rate change is requested; the ability of a carrier to average costs to it of gas purchased from many producers and fields enables, it to minimize the frequency with which it applies for changes. Under an interpretation of the act requiring a hearing each time any regulated entity decides to change its rates (and, in a rising market, producer rate changes frequently occur) the Commission has faced a fas greater burden in regulating the production end of the pipeline than it ever faced at the distribution end.

This administrative breakdown in the FPC emphasizes the debate over the propriety of the Phillips decision..$^{14}$ One aspect of this debate focuses on congressional intent, questioning whether the Natural Gas Act of 1938 was meant to provide for regulation of contracts between independent producers and pipelines. ${ }^{15}$ On a purely semantic level, the Phillips decision is firmly grounded in the Natural Gas Act, which grants the FPC jurisdiction over all sales of natural gas for resale in interstate commerce. ${ }^{16}$ While the statute exempts the production and gathering of natural gas, the production process, as the opinion in Phillips points out, ${ }^{17}$ is completed by the time of sale to the inter-

12. With a pipeline one can equitably divide all costs by units transported, but a producer's costs are not so easily divisible. One producer may spend $\$ 50,000$ to bring in a well that produces $X$ return, while another producer with $\$ 50,000$ might sink a well that returns 10X. Kaye, Extension of Federal Regulation of Natural Gas Production, 40 CokNeli L.Q. 328, 340-41 (1955). In addition, in the case of an integrated oil company that does not provide clear separations in its bookkeeping between natural gas and oil operations, a cost of service hearing for natural gas alone is practically impossible.

13. The pipeline maintains a current list for the FPC of all purchasing companies under each tariff. 18 C.F.R. $\$ 154.41$ (1961).

14. Belson, The Phillips Decision and Consequent Expansion of Federal Intrisdiction over Natural Gas, 43 Gro. L.J. 619 (1955); Durfee, Wisconsin and the Phillips Case, 55 Pvв. Utrl. Fort. 494 (1954); Ross \& Foster, Phillips and the Natural Gas Act, 19 Law \& Contemp. Prob. 382 (1954); and Roff, Jurisdiction of Federal Power Contmission to Regulate Sales of Casinghead Gas, 8 OkLA. L. Rev. 362 (1955).

15. Kay, Extension of Federal Regulation of Natural Gas Production, 40 CoRNelz L.Q. 328, 330-35 (1955) ; McLane, Jurisdiction of the Federal Power Commission over Production and Gathering of Natural Gas, 28 TuL. L. Rev. 343, 356 (1954); McLane, Jurisdiction of the Federal Power Commission over Production and Gathering of Natural Gas II, 28 Tur. L. REv. $462-67$ (1954) ; O'Leary, Jurisdiction of Federal Pozver Contmission under the Natural Gas Act, 32 Texas L. Rev. 762-66 (1954); Note, The Natural Gas Ait and State Price Regulation, 68 Harv. L. Rev. 148, 150 (1954); MacAvoy, Price Formation in Naturai Gas Fields 252-53 (1962) ; and Note, FPC Jutisdiction oucr Ficld Price of Independent Producers of Natural Gas, 54 Colun. L. Rev. 1149, 1152-53 (1954). All save the last article assert that producer regulation was not intended.

16. 52 Stat. 821 (1938), 15 U.S.C. § 717 (1958).

17. 347 U.S. $672,677-82$ (1954). 
state pipeline; the gas is then in the form in which it will ultimately be distributed to consumers. A literal reading, however, ignores the fact that neither Congress, in passing the Natural Gas Act, nor the seven-year agency investigation of interstate gas and electric companies which prompted passage of the act, explicitly considered the advisability of producer regulation or the problems that might arise if such regulation were undertaken. ${ }^{18}$ Prior to the adoption of the Natural Gas Act, regulation of the natural gas industry had been entirely a matter for the states. With the growth of interstate transportation and with the evolution of a near monopoly position by four major pipelines, the states became increasingly unable to regulate pipelines effectively. This inability was brought into focus by two Supreme Court cases placing constitutional bounds on the states' jurisdiction. ${ }^{19}$ The Natural Gas Act seems to have been passed to fill this regulatory gap - to institute federal regulation of the large pipelines, which the states had proved unable to regulate

18. S. Doc. No. 92, pt. 84A, 70th Cong., 1st Sess. 132-33, 184-97, 590-91 (FTC Utility Corporations Rep. 1935). This FTC report did not consider the problem of producer regulation. Whether Congress in acting upon the report considered independent producer regulation is a more difficult question to decide. The Court in Phillips quoted the following passage from H.R. REP. No. 709, 75th Cong., 1st Sess. 1-2 (1937) in support of its interpretation of the intent of the legislators of the Natural Gas Act as including producer regulation:

However, in the case of sales for resale, or so-called wholesale sales in interstate commerce (for example, sales by producing companies to distributing companies) the legal situation is different. Such transactions have been considered to be not local in character and, even in the absence of Congressional action, not subject to State regulation .... The basic purpose of the present legislation is to occupy this field in which the Supreme Court has held that the States may not act.

The Court felt that by this inclusion of "sales by producing companies to distributing companies" in the new area to which the Natural Gas Act extended federal supervision, i.e., the gap between federal and state regulation, the legislators exhibited an intent to regulate producer sales to pipelines. The purpose of the act was to extend regulation to interstate sales that could not be regulated by the states. The Supreme Court felt that the legislators were thinking of interstate sales by independent producers as a part of this gap.

In contrast to this view of the Court is the following exchange involving Senator Wheeler. It is typical of statements made by proponents of the act during its passage that are now used to support the proposition that sales between producers and pipelines were not considered to be covered by this legislation.

Mr. AUSTIN. Does the bill undertake to regulate the production of natural gas, or does it undertake to regulate the producers of natural gas?

Mr. WHEELER. It does not attempt to regulate the producers of natural gas or the distributors of natural gas; only those who sell it wholesale in interstate commerce....

81 Cong. Rec. 9312 (1937).

Most of the comments on the question of legislative intent support the view that Congress did not intend regulation of independent producers. See note 15 supra; Comment, Federal Price Control of Natural Gas Sold to Interstate Pipelines, 59 YALE L.J. 1467, 1510 (1950).

19. Public Util. Comm'n v. Attleboro, 273 U.S. 83 (1927) ; Missouri v. Kansas Gas Co., 265 U.S. 298 (1924). 
effectively. ${ }^{20}$ The scheme of regulation which Congress adopted in 1938 re= flects this narrow concern. Prior to Phillips the FPC had acted on the assumption, concurred in by most commentators, ${ }^{21}$ that producer regulation was not within the intent of the act. ${ }^{22}$

The second aspect of this debate, closely related to the problem of legislative intent, questions the wisdom of regulating independent producers. Even if the legislative history could be read to support the Phillips decision, sixteen years of consistent administrative interpretation of the act might have been reason for the Court not to have opted for regulation. Those who argue that producer regulation is needed rely most heavily on the continuing and rapid rise in natural gas prices, which began during World War II. ${ }^{23}$ Although this price rise is due largely to huge increases in consumer demand for natural gas, $^{24}$ there is some evidence - disputed by those who oppose producer regulation - that non-competitive pricing elements in the producer industry have

20. 81 Cong. Rec. 6721 (1937) (statement by Congressman Lea); 83 Conć. Rec. 2422-23 (1938) (statement by Senator Wheeler); Crenshaw, The Regulation of Natural Gas, 19 LAw \& Contearp. Prob. 336 (1954).

21. See note 15 supra.

22. Columbian Fuel Corp., 2 F.P.C. 200 (1940); Phillips Petroleum Co., 10 F.P.C. 246 (1951).

23. The general price situation for natural gas is one of long-run inflationary rise. For example, wholesale gas prices rose from an index level of 101.7 in 1958 to 127.5 in 1963, while wholesale prices for all commodities remained stable, dropping from 100.4 in 1958 to 99.9 in 1963. Dept. of Cosmarerce, Bureau of the Census, Statistrcal ABSTRACT OF THE U.S. 352 (1963). For the consumer price index, only figures combining electricity and gas are available, so that no reliable conclusion can be drawn for natural gas alone. The combined index for the two commodities rose at a rate roughly equivalent to the index for all commodities between 1950 and 1960. Worrd Almanac AND Book of Facrs 756 (1963). A 1963 Bureau of Labor Statistics survey of net monthly retail gas bills in twenty selected cities revealed that the retail price index for natural gas for use in cooking, water heating, etc. rose from 87.5 in 1950 to 106.6 in 1960 and 109.1 in 1962. For gas for use in residential heating, the rise was from 77.8 in 1950 to 112.1 in 1960 and 114.6 in 1962. Moody's Public Utruity Manual a68 (1963).

These rises are not properly explained as the result of increasing costs necessitating higher rates to allow the legal fair return on investments. Profit levels in natural gas have run well above the industrial average. For all natural gas companies the average percentage of sales represented by net income was 15.0 in 1947 and 8.6 in 1962. For the average of 452 industrials, the percentage was 6.8 in 1947 and 5.6 in 1962. Moody's INdustrial Manual al4 (1963). The 1960 sales total for all natural gas pipeline companies was 2-1/2 times the 1950 figures, while revenues were 5 times the 1950 amount. Plant investment went up 3-1/2 times and operating income quadrupled. 41 FPC ANN. REP. 66 (1961). Total income after taxes and before interest charges for all natural gas companies (excluding pipelines) was $\$ 636,923,000$ in $1959, \$ 709,731,000$ in 1960 , and $\$ 717,007,000$ in 1961. Dividends declared, combining common and preferred, for the three years were 297 million dollars, 319 million; and 361 million. Total assets for the three years were $\$ 11,422,131,000$ (1959), $\$ 11,986,331,000$ (1960), and $\$ 12,446,758,000$ (1961). The pipeline companies had a similarly favorable growth picture. 41 FPC ANN. REP. 105 (1961) ; 42 FPC ANN. REP. 151-53 (1962).

24. Crenshaw, The Regulation of Natural Gas, 19 LAw \& Contemp. Prob. 325 (1954). 
been in part responsible. ${ }^{25}$ If such elements exist, direct regulation of producers is economically justifiable as a means of preventing consumer exploitation. ${ }^{26}$ Producer states are unlikely to provide regulation, by such means as establishing maximum rates for producers. Indeed, they were setting mini-

25. One basis for the high rate of inflation in natural gas prices is the favored nation clause. See text following note 31 infra. A very elaborate process is followed by producers in estimating costs over the period of the contract, and the costs usually follow these estimates. Thus, favored nation clauses seem to provide an unjustified windfall. Where costs vary among producers in the same area, triggering of favored nation clauses produces highly inequitable results by equalizing all rates in the area. MAcAvoy, PrICE Formation in Naturat Gas Fyelds 265 (1962).

It is also argued that a generally noncompetitive level of field prices is produced by the combination of long-term contracts and favored nation and price redetermination clauses. Long-term contracts sharply reduce the existing available supply of gas for which there can be bargaining. New buyers must compete for the limited supplies not tied up with favored nation clauses. "As a consequence of focusing new demands upon a limited portion of total supply, prices are lifted above competitive levels." NEUNER, The Natural Gas Industry 222 (1960). Favored nation clauses also have a strong effect on prices by letting the strongest seller set the price level for all. Id. at 279. This often results in the absurdly dysfunctional situation in which pipelines construct lines in elaborate patterns around areas to avoid triggering clauses in the area. This, of course, lowers economic benefits for all except the producers by adding an unnecessary cost factor. MacAvoy, op. cit. supra at 264 (1962). There is some evidence of a general oligopoly situation in the industry, viewed nationally. In 1953, the twenty-five largest producers owned $45.6 \%$ of the known reserves of natural gas in the United States. The fifteen largest owned $39.5 \%$, the ten largest $34.9 \%$, and the five largest $27 \%$. NeunER, op. cit. supra at 16. As the Chairman of the Wisconsin Public Service Commission has pointed out, however, the appearance of the bargaining structure in the industry may be quite different at the local level. The Michigan-Wisconsin Pipe Line Co., at the time of the Phillips case, controlled 95\% of the sales of natural gas to Wisconsin, and Phillips Petroleum Co. had a monopoly of gas sold to this pipeline company. Phillips found itself in such a strong bargaining position that it felt free to threaten to turn off all Wisconsin's gas and let the state freeze if the Public Service Commission continued to prosecute the Phillips case. Phillips' contract price increased by $70 \%$ between the 1945 signing of the contract and 1950. A purchaser of coal or oil can move his supply base when the seller begins to demand unreasonable price rises, but a buyer of natural gas has made huge investments in pipeline facilities in the field of the producer, and has signed a long-term contract; both bind him to his source of supply. Durfee, Wisconsin and the Phillips Case, 55 Puв. UtTL. Fort. 70, 73 (1955).

26. The proponents of the act in 1938 clearly had such an objective (protecting consumers from inflationary exploitation) in mind. Senator Brown of Michigan, one of the bill's sponsors, made this statement on the ultimate goal of the act:

At the request of the Cities Alliance I have introduced in the Senate a bill which has for its uitimate objective a Nationwide reduction of gas rates and a saving of many millions of dollars to the American public each year.

81 Cong. Rec. 2488 (1937). In the House, Representative Halleck presented the same interpretation:

My opinion is that the operations of the Federal Power Commission in applying this act will be in the regulation of rates downward, not in the regulation of rates upward ....

81 Cong. Rec. 6724 (1937). Such an objective could be expected of an act which was in fact drafted by a committee of mayors interested in lower consumer prices. 81 Conc. REc. 2488 (1937) (statement of Senator Brown). This interpretation has also been given 
mum charges during this period of rise. ${ }^{27}$ Thus, if non-competitive pricing elements did exist in 1954, when Phillips was decided, they presented the same regulatory gap vis-a-vis producers as that which led to the imposition of federal regulation of pipelines in 1938. It was the existence of this regulatory gap, together with the intent of the act to prevent exploitation of the gas consumer, that the Supreme Court ultimately relied upon when it asserted in Phillips that the intent of the act was to regulate producers. ${ }^{28}$

The FPC's present dilemma serves to reinforce the conclusion that Congress did not consider the problems involved in regulating producers when it passed the Natural Gas Act in 1938. The Commission has found that its failure to limit the spiraling price increases and to recover from its administrative breakdown are due not merely to the vast increase in its caseload, but also to the inappropriateness to the peculiarities of producer regulation of the regulatory procedures established by the Natural Gas Act, as interpreted by the FPC since $1938 .^{29}$ In recent years, the Commission, seeking to repair the breakdown, has found it necessary to alter some of the procedures which it had been following - procedures which seem to have been contemplated by the act. A primary example of such alteration is the FPC's recent substitution of area rate regulation for its previous method of determining the cost

support by the Supreme Court, in its opinion in Atlantic Ref. Co. v. Public Serv. Comm'n, 360 U.S. 378, 388 (1959) : "The purpose of the Natural Gas Act was to underwrite just and reasonable rates to the consumers of natural gas." See also Sunray MidContinent Oil Co. v. FPC, 364 U.S. 137, 147 (1960) ; FPC v. Hope Natural Gas Co., 321 U.S. 591, 610 (1944).

27. Comment, Federal Price Control of Natural Gas, 59 YALE L.J. 1468, 1501 (1950).

28. 347 U.S. $672,682-85$ (1954). Whether or not the alleged non-competitive pricing elements exist, producer regulation could be justified as an anti-price rise device - as a means to protect the expectations of consumers and other buyers with long-term contracts for natural gas against loss of service or utter frustration of cost estimates. When entering into their contracts, those consumers had anticipated that prices under the long-term contracts would not burgeon to the levels that have been reached. Yet, it can be argued, protection of such consumers is doubtful justification for judicial alteration of the normal competitive processes, which in this case would operate to favor new, high bidders for gas as well as to induce producers to search for new sources of supply to meet the burgeoning demand. Such allocation of resources between broad classes of the citizenry is most often thought of as a matter of peculiarly legislative competence.

29. In 1954, shortly after Phillips, Commissioner Digby of the FPC declared:

The interpretation given to the Natural Gas Act by the Federal Power Commission over the sixteen years since its enactment was largely modified by this decision. As a consequence of such a situation, the FPC suddenly found it necessary to assume the new and added jurisdiction over the independent producers without rules and regulations reasonably applicable to such an operation. . . . It is my considered judgment that the public interest requires changes in the Natural Gas Act. Digby, The Natural Gas Act, 54 PuB. UTIL. ForT. 494, 495, 499 (1954).

The fact that the Commission has found it necessary to alter its regulatory scheme through area rates and the outlawing of indefinite escalation clauses discussed below is, of course, the clearest evidence that the old system is not well adapted to producer regulation. See also Pure Oil Co., 25 F.P.C. 383, 388, 390 (1961) and Kaye, Extension of Federal Regulation of Natural Gas Production, 40 CorNell L.Q. 328, 340-43 (1955). 
basis for each producer in a separate hearing. ${ }^{30}$ Under the area rate system, the Commission sets rates for all the producers in a particular area in a consolidated hearing. Each producer then has the burden of showing that the area rate should not be applied to him. The result of the area rate system is a substantial saving in time and effort.

The FPC's recent attempt to outlaw indefinite price escalation clauses marks another alteration of previous procedures. ${ }^{31}$ Indefinite price escalation clauses, contained in an original contract between a producer and a pipeline, authorize increases in price at frequent intervals over the term of the contract, typically ten to over twenty years. These clauses are generally of three types: "most favored nation" clauses, providing that the producer shall never receive less than any other producer in his area receives from the particular pipeline for the same grade of gas; price redetermination clauses, authorizing renegotiation of the price at specified times or at the request of one party; and automatic escalation clauses, establishing increases which will be based on the movement of standardized price indices. ${ }^{32}$ The inflationary effect of these

30. Wisconsin v. FPC, 373 U.S. 294 (1963). Under the area rate system implicitly sanctioned in this case, the FPC sets a separate producer rate for each natural producing area. Two prices are set for each of the twenty-three producing regions, one for initial requests for certificates and a generally lower one for price increase filings. The producer is free to agree to a price at, or less than, the maximum established. The rather cryptic regulations that have so far been adopted for area rates are found in 18 C.F.R. $\S 2.56$ (1961). The area prices follow the pattern that existed between 1956 and 1958 and provide a spread among regions. MacAvor, Price Formation in Natural Gas Fiedds 252-54 (1962).

In establishing area rates, however, the FPC discontinued a number of hearings it had set under $\S \S 4$ and 5 and allowed the rate increases to become final. The rates had been suspended subject to refund to the public, so that allowing the rates to take final effect simply discontinued regulation the Commission had been putting off due to its heavy burden of applications. Wisconsin v. FPC is a sequel to Phillips Petroleum Co. v. FPC, 347 U.S. 672 (1954), involving Phillips Petroleum Company's filing of a great many successive rate increases. The discontinuation of all the pending rate hearings appeared to be a total abdication of regulation to the Wisconsin regulatory commission, which took the matter to court. The opinion in the Wisconsin case by Justice Harlan tacitly accepted the principle of area rates and affirmed the action of the Commission. The dissent by Justice Clark, concurred in by Chief Justice Warren, Justice Black, and Justice Brennan, presented the view that area rate was an abandonment of regulation past and present on the hope that at some future date area rates would solve the problem. Thus, the system, upon which the Commission pins many of its hopes for working out the Phillips-CATCO dilemma, has received but a narrow, and perhaps temporary, approval from the Supreme Court. Cf. FPC v. Hunt, 84 Sup. Ct. 861, 868 (1964).

31. This attempt was made by means of three orders to be discussed below. They are: Order 232, 25 F.P.C. 381 (1961), declaring the clauses unlawful with two exceptions; Order 232A, 25 F.P.C. 609 (1961), adding a third exception; and Order 242, 27 F.P.C. 339 (1962), providing for the automatic rejection of applications for certificates of public convenience and necessity based on contracts containing the clauses. The specific Commission rules amended and the effects of these efforts are discussed in the text below.

32. In fiscal $195 \%, 14 \%$ of the contracts of 1-9 years, 34\% of those of 10-19 years, and $69 \%$ of the contracts of 20 years or longer had either favored nation or renegotiation clauses. MacAvoy, Price Formation In Natural Gas Fields 31 n.7 (1962). The per- 
clauses and their contribution to the breakdown of FPC administration arise from their relationship to the Commission's procedures for reviewing rate increases. Any proposed change in price must first be contractually agreed upon by the producer and pipeline, either through a rate-changing provision in the original long-term contract or through voluntary modification of that contract. $^{33}$ Section 4 of the Natural Gas Act requires the parties to give thirty days notice of any change in rates to the Commission. Unless the Commission takes some action, the proposed changes will take effect after the expiration of that period. The FPC may approve the proposed change with or without hearing, or it may reject the proposal after a hearing. Finally, within the thirty day period the FPC can generally suspend the effective date of the changes for an additional five months, during which time the Commission can act on the proposal. If no action is taken within the six month period from the date of filing, the rates become effective subject to provision for rebates should the FPC later find the prices to have been unreasonable. ${ }^{34}$ Since escalation clauses are often invoked several times in a single year to implement rate increases provided for by the contract between the producer and the pipeline, the Commission has been burdened by its efforts to examine each proposed increase and to hold hearings when appropriate $;^{\mathbf{3 5}}$ in some cases it has been impossible to hold a hearing - a prerequisite to rejection - even within the six month period. ${ }^{36}$ Thus many price changes surely not warranted by the FPC's regulatory goals - whether they be the elimination of non-competitive pricing elements or the maintenance of costjustified prices - become effective after six months on the motion of the applicant. ${ }^{37}$ The statutory rebate provision has not proved to be an effective

centage of all contracts having such clauses is about $65 \%$, since 874 of the 997 new contracts submitted to the FPC during this period had terms of twenty years or longer. Id. at $30 \mathrm{n} .4$.

Professor MacAvoy declared that favored nation and renegotiation clauses have not been serving their supposed purpose of transferring from producer to pipeline the risk of a price that is too low. He infers this conclusion from the fact that "actual contract prices did not indicate any clear tendency to be lower for contracts containing clauses, than for those without clauses during the 1950's." Id. at 264.

33. United Gas Pipe Line Co. v. Memphis Light, Gas \& Water Div., 358 U.S. 103 (1958) ; United Gas Pipe Line Co. v. Mobile Gas Serv. Corp., 350 U.S. 332 (1956).

34. 52 Stat. 822-23 (1938), 15 U.S.C. $\$ 717$ (c) (1958).

35. For example, the Phillips Petroleum Company, after losing the Phillips case, filed twelve successive $\$ 4$ rate increase requests between June, 1954 and May, 1956. All were suspended for the maximum period and allowed to become effective subject to hearing and refund. Between 1956 and 1959 the company initiated 100 additional rate increase proceedings. The first twelve were given permanent effect without a Commission hearing when it embarked on a system of area-wide rates, and the action of the Commission was ultimately upheld by the Supreme Court. Wisconsin v. FPC, 373 U.S. 294 (1963). Thus, by continually filing rate increases in such large numbers that the Commission is unable to act on them, the producers are able to keep rates moving up without any effective agency regulation.

36. 52 Stat. $822-23$ (1938), 15 U.S.C. \$717(c) (1958).

37. Ibid. 
means of combatting this situation, and has seldom been used. ${ }^{38}$ By the time the FPC can hold the hearing necessary for a rebate, several additional rate increases may have been filed and become effective. ${ }^{39}$ Consequently, a decision to deny a rate increase and compel a refund would affect only the relatively short period between the time that the denied rate increase went into effect and the time the next requested increase became effective.

38. The Commission analyzed the problem of refund to the consumer in the following manner in 1953:

The Commissioner recognizes that the collection of higher rates under bond, while providing protection to the pipeline company against ultimate loss in revenues, is unsatisfactory, burdensome and presents many difficult problems for the company as well as for the distribution facilities which must pay the higher rates. The problem of distributing impounded funds to consumers in the event that proposed rate increases are denied even in part is time-consuming and expensive.

33 FPC ANN. REP. 101 (1953).

In its annual reports from 1953 to the present the Commission entered into extensive detail concerning rates disallowed by agency action, but avoided any but the most scant reference to its success in having refunds distributed to consumers. 33 FPC ANN. REP. 101 (1953), 34 FPC ANN. REP. 108 (1954), 35 FPC ANN. REP. 110-11 (1955), 36 FPC Ann. Rep. 82 (1956), 37 FPC Ann. Rep. 81, 87 (1957), 38 FPC ANs. Rep. 71, 72, 73, 76 (1958), 39 FPC ANn. Rep. 78, 82 (1959), 40 FPC AnN. Rep. 74, 78 (1960), 41 FPC Ans. Rep. 76, 79 (1961), and 42 FPC Ann. Rep. 96, 106 (1962). See also FPC v. Tennessee Gas Transmission Co., 371 U.S. 145, 154, 155 (1962).

39. Section 4 of the Natural Gas Act, 52 Stat. 823 (1938), 15 U.S.C. $\S 717$ (c) (1958), provides:

Where increased rates or charges are thus made effective, the Commission may, by order, require the natural-gas company to furnish a bond, to be approved by the Commission, to refund any amounts ordered by the Commission, to keep accurate accounts in detail of all amounts received by reason of such increase, specifying by whom and in whose behalf such amounts were paid, and, upon completion of the hearing and decision, to order such natural-gas company to refund, with interest, the portion of such increased rates or charges by its decisions found not justified.

As the Supreme Court pointed out in Atlantic Ref. Co. v. Public Serv. Comm'n, 360 U.S. 378 (1959), the refund provision is intended to give full protective coverage to the consumers by guaranteeing that they will be able to recover sums paid under excessive increases. However, it has in fact merely provided protection for the pipeline or producer against operation under a rate that is too low by allowing collection of questionable rates until the reasonableness of the rate can be determined by the Commission. The FPC has at times relied upon: makeshift devices in attempts to get refunds passed on to consumers. In 1958 the agency declared that:

During the fiscal year several rate cases were settled by agreement of all parties .... In cases of this type the settlements have been conditioned on the purchasing company passing on to its customers any refunds it may ultimately receive from the supplying company.

38 FPC ANn. REP. 73 (1958).

The ultimate distribution of sums to consumers is a complex and expensive process to undertake months or years after the sums were paid. With the Commission already burdened down to the breaking point with regulatory business, the supervision and review of refunding is highly impractical, as the Commission has recognized. 33 FPC ANN. REP. 101 (1953). 
In an effort to combat the harmful effects arising from the use of indefinite escalation clauses, the Commission promulgated Order 232.40 This rule provides, with two minor exceptions, that any producer-pipeline contract subject to FPC jurisdiction and executed after April 3, 1961 will be denied a section 7 certificate of public convenience and necessity if it contains changein-price provisions. Under section 7 of the act, producers and pipelines (or pipelines and distributing companies) must negotiate a contract covering all aspects of their prospective relationship and submit it, together with an application for a certificate of public convenience and necessity, to the Commission, before gas sales can be initiated. After a hearing the Commission generally either grants the certificate, which accords permission to commence delivery according to the terms of the private contract, or denies the application. In some instances it grants the certificate subject to a condition that the parties alter the price or amend the contract in one or more respects. ${ }^{41}$ The price change provisions excepted from the ban of Order 232 were "definite" escalation clauses - providing either for direct reimbursement for changes in various taxes on the seller, or for changes in price to a specified amount at a definite date. Approximately one month after Order 232 was issued, the Commission issued Order $232 \mathrm{~A}^{42}$ amending Order 232 and creating an additional exception to the general proscription of escalation provisions. Under this rule a contract, if it contains no provision for changes in price to specified amounts, can provide for a redetermination of the price once every five years to a level not higher than rates approved at that time by the Commission for producers in the same area. These orders, thus, seek to reduce the Commission's workload by reducing the number of occasions on which section 4 filings ${ }^{43}$ can be contractually authorized between the parties.

On February 8, 1962, the FPC supplemented these orders with Order 242,44 which provides that an application for a section 7 certificate of public convenience and necessity will be rejected without a hearing if the contract between the parties contains the clauses proscribed under Orders 232 and 232A, unless one of the parties can adduce prima facie evidence that the general ban on in-

40. 25 F.P.C. 381 (1961), amending 18 C.F.R. $\S \S 154.91,154.93$ (Supp. 1963).

41. Section 7 of the Natural Gas Act provides that "no natural-gas company shall undertake the construction or extension of any facilities for the transportation of natural gas" without a certificate of public convenience and necessity from the FPC. The Commission can attach to a certificate certain conditions required by the public convenience and necessity. The section provides for a hearing on all properly submitted applications. 52 Stat. 824-25 (1938), 15 U.S.C. § 717(f) (1958).

42. 25 F.P.C. 609 (1961), amending 18 C.F.R. \$\$ 154.91, 154.93 (Supp. 1963).

43. Section 4 of the Natural Gas Act provides that all rates for interstate sale of natural gas shall be "just and reasonable" and requires a notice of any proposed change in rates to be filed with the FPC thirty days before it is to take effect. 52 Stat. 822-23 (1938), 15 U.S.C. \$717 (c) (1958).

44. 27 F.P.C. 339 (1962), amending 18 C.F.R. $\S \S 154.93,157.14(\mathrm{a})(10)(v), 157.25$ (Supp. 1964). 
definite price escalation clauses should be waived in his particular case. ${ }^{45}$ Two appeals from FPC action denying section 7 applications without hearing, on the authority of Order 242, produced conflicting decisions in the courts of appeals. The courts divided on the Commission's power to promulgate the rules and its authority to deny the applications without hearing. In Superior Oil Co.v. FPC ${ }^{46}$ the Ninth Circuit Court of Appeals upheld all of the orders. In FPC v. Texaco, Inc. ${ }^{47}$ the Tenth Circuit found Order 242 to be void, while holding the other orders valid; the court interpreted Orders 232 and $232 \mathrm{~A}$ as merely advisory proclamations of FPC policy rather than determinations of rights. The Supreme Court granted certiorari and reversed the Tenth Circuit in Texaco ${ }^{48}$ and denied certiorari in Superior, ${ }^{49}$ thus resolving the conflict between the circuits in favor of the Ninth Circuit's interpretation in the Superior case.

The two circuit courts had differed in their interpretation of the hearing requirement in section 7 of the act concerning applications for certificates of public convenience and necessity. The Tenth Circuit in Texaco had rested its finding of the invalidity of Order 242 on the literal words of section 7 ,

45. Order 232 was issued on March 3, 1961; notice of proposed rule making had been published originally in the Federal Register on April 12, 1956, 21 Fed. Reg. 2388 (1956). The order amended Commission regulations 18 C.F.R. \$\$ 154.91, 154.93 (Supp. 1963) which define rate schedules to be filed. Order 232A was issued on March 31, 1961, and modified 232 in its amendment of the above regulations. Order 242 was issued on February 8, 1962, after notice of proposed rule making published on October 10, 1961, 26 Fed. Reg. 9732 (1961). This order amended Commission regulations under the Natural Gas Act, 18 C.F.R. $\$ \S 154.93,157.14(\mathrm{a})(10)$ (v), and 157.25 (Supp. 1963). These regulations provide definitions of rate schedules and specification of material to be submitted with certificate applications. Section 154.93 provides that a "rate schedule" to be filed with applications for certificates includes the basic contract and all supplemental agreements (amended to void all indefinite price change clauses). Section $157.14(\mathrm{a})(10)(\mathrm{v})$ provides that a copy of every gas purchase contract subject to FPC jurisdiction must be filed with the Commission (amended to provide that any contract executed after April 2, 1962 , with indefinite price change provisions as defined in $\$ 154.93$ would "be given no consideration in determining adequacy of gas supply," which means that the pipeline would be denied its application for inadequate reserves). Also involved in the litigation under consideration here is 18 C.F.R. $\$ 1.14$ (a) (2) (Supp. 1963). This rule provides in part: "There will be accepted for filing only such applications, pleadings, and other papers as conform to the requirements of this part, and any other applicable rule, regulation, or order of the Commission or applicable statute." Under this rule the FPC can argue that it is rejecting the application for defective form of the papers, but such a position begs the question of the validity of the rule to which the form of the application did not conform.

46. 322 F.2d 601 (9th Cir. 1963).

47. 317 F.2d 796 (10th Cir. 1963), rev'd, 377 U.S. 33 (1964).

48. FPC v. Texaco, Inc., 377 U.S. 33 (1964).

49. Superior Oil Co. v. FPC, 322 F.2d 601 (9th Cir. 1963), cert. denicd, 377 U.S. 922 (1964). 
which provide that no certificate can be denied without a hearing. ${ }^{50}$ In Texaco, the Supreme Court, as the Ninth Circuit had done in Superior, held that United States v. Storer Broadcasting Co. ${ }^{51}$ was controlling. In Storer the FCC was upheld in rejecting an applicant for a license without hearing, because his application revealed on its face a failure to conform with established FCC standards dealing with the problem of multiple station ownership. It is important to note that the Court based its decision on a finding that the substance of the rule was within the statutory mandate of the FCC. Reaffirming the Storer holding, the Court in Texaco asserted that "the statutory requirement for a hearing under $\S 7$ does not preclude the Commission from particularizing statutory standards through the rule-making process and barring at the threshold those who neither measure up to them nor show reasons why in the public interest the rule should be waived." 52 If orders 232 and $232 \mathrm{~A}$ are valid - an issue on which the two circuit courts agreed, though for different reasons - it would be fruitless for the FPC to hold a hearing on a certificate application where the contract contains the forbidden clauses and the applicant does not make application for waiver of the rules, ${ }^{53}$ for the only possible result of a hearing would be denial of the certificate.

However, the Storer rationale has vitality only where the agency rules are substantively valid. Unless Orders 232, 232A and 242 were within the power of the FPC, Storer could not save the Commission's rules. The Supreme Court relied primarily upon its decision in Atlantic Refining Co.v. Public Scrvice Comm'n (CATCO $)^{\text {s4 }}$ in sustaining the Commission's authority to proscribe indefinite escalation clauses in a section 7 proceeding. In $C A T C O$ the Court found that the FPC had authority to review the propriety of contract

50. Section $7(\mathrm{c})$, with one exception that became permanently inoperative in 1942, provides that in all cases of an application for a certificate:

... the Commission shall set the matter for hearing and shall give such reasonable notice of the hearing thereon to all interested persons as in its judgment may be necessary under rules and regulations to be prescribed by the Commission. . . .

52 Stat. 824-25 (1938), 15 U.S.C. § 717(f) (1958).

51. 351 U.S. 192 (1956).

52. 377 U.S. 33,39 (1964).

53. If the producer feels his fact situation does not come within the given rule, or that his case involves special circumstances, he can apply for waiver of the rule. 18 C.F.R. $\S 1.7$ (b) (Supp. 1963).

54. 360 U.S. 378 (1959).

In $C A T C O$, the Commission had attached a rate condition to the granting of a certificate for the sale of the largest segment of offshore reserves theretofore channelled into the interstate system. However, the producing companies refused to agree to the rate condition and threatened to withdraw the supplies from the market if it were not removed. The condition had been applied to prevent rapid price increases due to a complex of most favored nation clauses in existing contracts, which would have been triggered by the unusually high initial prices in the proposed contract. The FPC rescinded the condition. On appeal, the Supreme Court declared it was the duty of the FPC under $\S 7$ to examine the initial rate, and if it proved contrary to the public convenience and necessity, to attach a rate condition. 
rates and to attach conditions to a certificate in section 7 proceedings. Though the section does not contain explicit language authorizing an examination of initial contract rates, the term "public convenience and necessity" was found to justify the imposition of rate conditions. Thus where the FPC rejects a proposed rate as being opposed to the public interest, it can attach a condition to the granting of the certificate requiring the parties to amend the rate terms of their contract. In both CATCO and Texaco the Court was prompted to allow the Commission power to control terms of initial price to sustain what it considered to be among the dominant aims of the Natural Gas Act - "protection of consumer interests." The Court in Texaco asserted that price control "may be best achieved if it is done at the very threshold" of the regulatory process. ${ }^{55}$

There is, however, a significant difference between $C A T C O$ and Texaco. In $C A T C O$ the rate conditions to which the Court gave its sanction were to be applied on an $a d$ hoc basis, and the parties to the contract were always to be free to proceed under section 4 for a rate increase. The conditions involved in Texaco were to be applied by the Commission to all certificate applications. When the FPC imposes a rate condition, it is making a judgment that at the particular moment a certain rate is economically sound in view of existing circumstances. Such rates are intended to remain effective for several years. However, the act provides means whereby rates which become inappropriate due to changed economic circumstances may be adjusted. Among the devices available to effect price adjustments are price escalation clauses and statutory rate-changing proceedings either on application of the producer and pipeline under section 4 or by the FPC under section 5 . The ban of Orders 232 and $232 \mathrm{~A}$ renders these means of price readjustment unavailable. Under the orders, producers when negotiating rates, and the Commission when approving them, are compelled to make economic predictions which will usually be binding for at least five years.

Five year predictions in the natural gas industry will generally prove reliable. By the time a contract is signed for the purchase of gas, the producer's cost structure is usually sufficiently clear, and will seldom be disturbed by significant fluctuations during the contract term. Most of the producer's costs are incurred early in the production process, i.e., in drilling and establishing delivery facilities. Geological surveys of depth, volume and pressure of the gas reserves determine with fair reliability what the producer's costs will be during the production period. In normal times inflation can be expected to continue at a fairly constant rate, allowing the producer to estimate with some certainty the effect of a generally rising price level upon his costs. The remaining major investment for the producer occurs in the final years of production, when he must withdraw gas under pressure reduced by gradual exhaustion of the particular reserve. This factor is estimated at the time the contract is first negotiated and the initial well pattern is drilled

55. 377 U.S. 33,42 (1964). 
so that an agreed percentage of the gas underground can be recovered over the life of the contract. ${ }^{56}$ Typically, contracts for sale of gas have a term of as few as ten to as many as thirty years, with the majority falling into the twenty to thirty year range. ${ }^{57}$ Thus, even with the shortest contracts, price redetermination if allowed every five years will generally afford at least one opportunity to adjust price during the life of the agreement. Considering the unlikelihood of major price fluctuations within a five year period, and the ability of the parties to a contract to estimate their five year cost pattern with substantial reliability, the Commission's regulations proscribing escalation clauses seem to permit a sufficient degree of flexibility.

Since the need to reduce the Commission's case backlog is now acute, Orders 232 and 232A might appear to be justified in view of the relatively slight uncertainties which they will introduce into price determination. The Supreme Court presumably was referring to section 7 proceedings, rather than those under section 4, when it stated in Texaco that consumers would be best protected by price regulation at the "threshhold." 58 The Court supported this view by citing legislative history:

The bill when enacted will have the effect of giving the Commission [FPC] an opportunity to scrutinize the financial set-up, . . . and the characteristics of the rate structure . . . at a time when such vital matters can readily be modified as the public interest may demand . . . .59

56. Thus, costs of production are not spread evenly over time, but follow a pattern requiring huge initial outlays, small costs for a number of years, and another large expenditure to withdraw the last portion of gas from the trap. Pipeline companies "buy" the gas reserve in the ground, based upon an estimate, usually accurate, of the volume recoverable. Because they agree to pay for about $80 \%$ of expected volume even if actual production falls short, pipelines will not accept an estimate made before $20-40 \%$ of the number of wells that will be drilled for full production are completed. Since the pipeline companies must deliver uniform amounts to the city distributing companies over long periods, they require guarantees from the producers of a uniform delivery for the duration of the contract period. By specifying drilling patterns at the time the contract is entered, the pipelines can be reasonably assured that estimates are accurate and that gas will be produced at a rate suited to the contract specifications. State regulation, through proration, guards against premature depletion, and FPC regulation under section " requires a showing of the adequacy of reserves so that all withdrawal plans must be stated in advance. With the major cost of drilling established and rate of delivery and reserves known, the contracting parties will be able at the start to reach an estimate of the return necessary to assure the producer a suitable profit. It would seem that fluctuation in production costs and the anticipated cost of withdrawal of the last gas under conditions of low pressure could be adequately accounted for by contract price revision at widely spaced, periodic intervals. Given an average contract term of twenty years, five year intervals seem sufficient. And, since the delivery rate is specified in the same contract which sets the rate, pipelines will be unable to milk profits from producers by insisting on disproportionate delivery levels at the contract rate, in the event of a rise in the market as a whole. MACAvoy, Price Foramation in Natural Gas Fields 10, 13-17, $29-30$ (1962).

57. In fiscal 1957, of 997 new gas purchase contracts submitted to the FPC, 874 were for terms of twenty years or more. $I d$. at 30 n.4.

58. 377 U.S. 33,42 (1964).

59. Id. at $43-44$. 
However, the provision in the statute of a means whereby the Commission can modify proposed contracts on a case-by-case basis does not necessarily indicate that Congress intended to permit the Commission to modify all contracts by means of a blanket pronouncement of general and future applicability. The existence of section 4 of the Natural Gas Act seems to manifest a congressional intention that parties to a contract for sale of gas be able to initiate proceedings for redetermination of price whenever they feel that economic conditions require them to do so. Section 4 allows the Commission to examine applications for proposed rate changes prior to the time they are to become effective. This section 4 device has the virtue of permitting the price to be established on the basis of a judgment concerning existing conditions, rather than upon what must be a less accurate judgment about the future. ${ }^{00}$ While the Supreme Court has never interpreted section 4 as incorporating a right to contract for price-changing clauses, it has held that section 4 does not prohibit a contractual term which gives one or both of the parties the right to adjust the price without consulting with the other party. ${ }^{61}$

In FPC v. Hunt, ${ }^{62}$ decided at the current term, just three weeks before Texaco, the Court considered the functional relationship between sections 4 and 7 of the act. In Hunt the validity of an FPC-imposed condition on the grant of an emergency certificate under section 7 was challenged. ${ }^{03}$ The condition required that there be no change in the temporarily authorized rate until a permanent certificate was granted. The Court upheld the imposition

60. Commissioner Kline in dissenting to Order 232 stated :

It is impossible for anyone to predict with accuracy the economic conditions so far in the future, what the costs of a producer will be at that time, or what will constitute a just and reasonable price for gas. . . In summary, I am opposed to the rule as written, .... and I believe a producer should not be required at his peril to attempt to set prices twenty years in the future, but should be afforded some reasonable means of negotiating a price at a time when he knows the conditions with which he will be faced.

Order No. 232, 25 F.P.C. 379, 381-82 (1961). A basic reason for concern over price flexibility is that gas companies are captives once they have agreed to provide service, as section 7 prevents withdrawal of service without FPC approval. 52 Stat. 824 (1938), 15 U.S.C. $\$ 717$ (f) (b) (1958).

However, relief from inflexibility in the orders of the Commission is available in the provision for waiver. In the case of unusual economic circumstances the producer could apply for a waiver of the rule in his case under 18 C.F.R. § 1.7(b) (Supp. 1963). This would avail in a certificate proceeding only if the company could show circumstances requiring waiver of the rule for the life of its contract, which is unlikely. In a rate change proceeding under section 4 it would apply only if the producer had been able to negotiate a new rate change clause with the pipeline to enable him to come to the Commission with his request for a waiver. If he did not, the Commission would reject the rate change for lack of contractual authorization. Thus, it would seem that the provision for waiver provides little actual protection once the escalation clause has been purged from the contract.

61. United Gas Pipe Line Co. v. Memphis Light, Gas \& Water Div., 358 U.S. 103 (1958).

62. 377 U.S. 515 (1964).

63. 52 Stat. 825 (1938), 15 U.S.C. $\$ 717(\mathrm{f})(\mathrm{c})$ (1958). 
of the condition against a challenge that it denied a right granted by section 4 to apply for a change in price at any time. The Court grounded its holding in the notion that temporary emergency certificates are granted without a full hearing in ex parte proceedings. It felt that the peculiar nature of the proceedings and the need to protect consumers of natural gas justified the Commission's applying a broad discretion prior to the time at which all the relevant evidence would be examined in a public hearing. Thus, the Court resolved the conflict between section 4 and section 7 by holding that section 4 is inapplicable until a permanent certificate has been granted. There was a strong implication in Hunt that the effective abrogation of section 4 by the imposition of conditions under a permanent certificate would be considered by the Court when that issue was squarely before it. However, in Texaco, decided only three weeks later, the Court failed to treat adequately the conflict between the two sections. It is possible that sub silentio the Court felt that the two cases were distinguishable since in Hunt proscription of section 4 proceedings was imposed by the FPC on a case-by-case basis while in Texaco the proscription was based on a general rule to be applied to all applicants. The Court hinted that this might underlie its thinking in its declaration that the FPC did not have to follow the procedures of sections 2 and 5 of the Administrative Procedure Act, ${ }^{14}$ because in Texaco the Commission was merely determining the qualification of applicants and was not undertaking an adjudication. The Court declared that the rule-making hearings which were held by the FPC when it promulgated Orders 232, $232 \mathrm{~A}$ and 242 were adequate. ${ }^{65}$ It thus sustained the Power Commission's authority to deal with indefinite escalation clauses at the initial stages of the regulatory process. At that stage the FPC will be permitted to attach a section 7 condition which will in effect deprive the parties of future recourse to section 4.

The Texaco decision has presumably resolved the question of the interrelationship between sections 4 and 7 for the present. It is disturbing, then, that Texaco seems to conflict with Hunt. In Hunt the Court accepted the concept of a right to file rate increases under section 4, but asserted that this right only applies in the case of permanent certificates; Texaco finds the Court permitting the Commission to limit severely the availability of section 4 , without ever having explicitly examined how it interplays with section 7 . The Court should have squarely faced these difficult problems in Hunt and Texaco. As written, the two decisions fail to clarify the extent of the Commission's power to undercut section 4 availability. Both of the cases seem willing to allow the Commission to circumvent the statutory mandate to some extent in order to provide a needed amount of flexibility in the regulatory scheme; yet

64. Administrative Procedure Act $\$ \$ 2$ and 5, 60 Stat. 237, 239 (1946), 5 U.S.C. $\$ \S 1001,1004$ (1958).

65. The facts to be examined in a hearing on the points raised by Texaco are common to most producers. A trial-type hearing to establish "adjudicative facts" is not necessary. Thus, a hearing appropriate to gathering "legislative facts" is called for, and the FPC's rule-making hearing was adequate. See 112 U. PA. L. REv. 909, 916 (1964). 
they fail to say how far the FPC may go. Surely the Commission could not permanently prevent the parties from seeking a rate increase, but short of this there is no certainty.

If the Court had faced these issues it would have recognized that its decision - motivated by the need to make the Phillips decision ${ }^{66}$ a viable one represented a further warping of the scheme which the act envisioned. ${ }^{67}$ It was the Court's decision in Phillips which brought on the acute administrative breakdown which Orders 232 and 232A seek to remedy. On several occasions since Phillips the Commission has been forced to alter its previous procedures and interpretations of the act so that the Phillips mandate could be followed. Shortly after the decision in that case, convinced that the Court had misin'terpreted the original intent of the Natural Gas Act, the FPC recommended to Congress that the act be amended to overrule Phillips. A bill which would

66. See text at notes 1-29, supra.

67. Several issues of statutory power to prescribe Orders 232,232A, and 242 are also raised by the silence of Congress in the face of repeated requests by the FPC for authority that would cover the orders it eventually issued. From 1956 through 1960 the Commission requested each year in its report that Congress enact legislation to provide:

... elimination of clauses in independent producers' contracts of sale to interstate gas transmission companies which contain provisions for a change of price to the purchaser by reason of (a) changes in the price received by the purchaser on resale, or (b) the payment or offer of payment of different prices by the purchaser or other purchasers to the seller or to other sellers.

36 FPC Ann. Rep. 19 (1956); 37 FPC Ann. Rep. 25-26 (1957); 38 FPC Ann. Rep. 15-16 (1958) ; 39 FPC ANN. Rep. $18-19$ (1959) ; 40 FPC ANN. Rep. 17 (1960). And in 1962 it recommended that Congress:

Amend section $7(\mathrm{c})$ to eliminate the mandatory hearing requirement, substituting in lieu thereof a provision for due notice and opportunity for hearing. As noted above with respect to the abandonment provision in section $7(\mathrm{~b})$, there are many cases in which neither the interest of the parties nor the public welfare requires that a formal hearing be held, and to do so only causes unnecessary delay. A hearing would be held when protests by interested parties raising substantial factual issues are received or when the Commission deems a hearing necessary in the public interest.

42 FPC ANN. REP. 16 (1962).

Such a pattern of agency and congressional action would seem to indicate that the power was not granted by the statute originally. On the other hand, there are many possible reasons for the silence of Congress - disinterest in the whole area; preoccupation with other bills considered more important; tentative approval, but delay for attack on a broader front; indecision; or belief that the courts should decide. Hart \& SAcrs, Tre Legal Process 1395-96 (1958). Moreover, at the same time in 1956 that the Commission was requesting, in clause (5) of its recommendations headed "Natural Gas Act - Regulation of independent producers," that indefinite escalation clauses be outlawed, it was also recommending in clause (1) the "elimination of any requirement for certificates of public convenience and necessity for producers of natural gas." 36 FPC ANN. REP. 19 (1956). Since, if producers were exempted from regulation, it would have been clear that the FPC did not have the statutory authorization to proscribe escalation clauses, the FPC's request need not be taken as a denial of the power to do so when they had the statutory power to regulate producers generally. Consequently the silence of Congress in the face of an attempt of the FPC to have legislation passed authorizing its actions most ascurately interpreted is simply ambiguous. 
have accomplished this purpose was passed by Congress. However, President Eisenhower vetoed it as a result of public disclosure of improper circumstances surrounding the passage. ${ }^{68}$ The Commission has now become reconciled to the additional regulatory responsibilities which Phillips thrust upon it, and has embarked upon an ambitious program in order to implement its new role. ${ }^{09}$ It is within this context that the Court should have examined the challenged orders in Texaco as they relate to the statutory intent. The Court merely noted the burden which Phillips placed upon the FPC, but otherwise failed to consider its relevance. 'The Court could have answered the questions left unanswered in $H u n t$ by explicitly declaring that Orders 232, 232A and 242 must be sustained, even if the effect will be to undercut the apparent purpose of section 4 to allow rate adjustments to be initiated at any time, on the ground that the Commission must have such power if the regulation of producers under Phillips is to be effective. Nothing could be worse than the half-hearted regulation of producers that would result if the Commission could not prohibit escalation clauses. In those circumstances, the FPC, while it would appear to have authority ample to regulate producers, would in reality become so overburdened that it could not effectively discharge its tasks. That type of regulation would not provide protection against the kind of rapid price rises which Phillips envisioned. However, it would create the illusion that a solution had been reached, and other institutions, such as Congress, might be lulled into the belief that Phillips had provided a panacea.

If regulation of the sale of natural gas is to be effective, the courts must be prepared to permit the FPC a fair amount of discretion in departing from the scheme of regulation which the act contemplated. The procedures of the act were adopted and first interpreted at a time when the only regulation envisioned was of contracts between pipelines and distributing companies. In Hunt the Supreme Court explicitly recognized that many of the procedures of the act were not well suited to producer regulation and noted the need for the FPC to streamline its procedures so that its docket backlog can be reduced. It specifically suggested another solution which the Commission might adopt the promulgation of jurisdictional standards, similar to those employed by the NLRB, in order to narrow the number of cases coming within its jurisdiction. ${ }^{\mathbf{7 0}}$ While such a proposal may seem superficially attractive, it probably cannot be justified under the act. The regulatory schemes envisioned in the labor field and the natural gas field are not alike. The nature of the regulated parties are dissimilar. The NLRB has potential jurisdiction over a vast num-

68. 102 CoNG. REc. 2793 (1956).

69. The FPC recommended the elimination of any requirement for certificates for producers for several years after Phillips. 36 FPC ANN. REP. 19 (1956); 37 FPC ANN. ReP. 25 (1957) ; 38 FPC ANN. ReP. 15 (1958) ; 39 FPC ANN. REP. 18 (1959) ; 40 FPC ANn. ReP. 17 (1960). The recommendation was not repeated in the 1961 report, 41 FPC ANN, REP. 2-3 (1961), and the Commission, accepting producer regulation, embarked upon the area rate method of producer regulation. 42 FPC ANN. REP. 101-04 (1962).

70. Cf. Guss v. Utah Labor Relations Bd., 353 U.S. 1, 3-4 (1957). 
ber of business units, of varying sizes engaged in a multitude of diverse business activities. The Natural Gas Act, however, seeks to provide a unitary regulatory scheme for one industry which is by and large dominated by a number of formidable producers. While it is difficult to assess the merits of the Court's suggestions, it is likely that in order for such a system to result in a meaningful reduction in the FPC's case backlog, jurisdictional standards would have to be set quite high. There are thousands of individual interstate producers, but the buik of gas is produced by a relatively small number of large scale producers. ${ }^{71}$ Thus, standards which would effectively limit the number of applications coming to the Commission would probably exempt a substantial proportion of all producers from regulation, and effective regulation of natural gas prices might become impossible. This danger is heightened by the likelihood that consumer demand for gas will continue to increase. Those producers made exempt by jurisdictional limitations might not be subject to state regulation, as the federal act may be found to pre-empt the field. Thus under the existing statute the Commission would be well advised not to take up the Court's suggestion to promulgate such standards.

The Supreme Court has forced itself into a troublesome position as a result of its Phillips decision, which requires the FPC to apply to the regulation of producers of natural gas procedures which were designed to implement the regulation of distributors. Since the Court seems unwilling to overrule Phillips, it will have to continue to allow distortion of the statute's procedural standards. The Commission has apparently recovered from the lethargic attitude which once characterized it and is now conscientiously seeking ways to reduce its docket backlog and to curtail the spiraling pattern of natural gas prices. Such efforts, of which the orders attacked in Texaco are only a part, are necessary if there is to be any effective regulation. The Court has shown itself willing to permit the Commission to indulge in experimentation with its procedures in order to attain a more workable regulatory pattern, albeit at the expense of restrictions on the right of producers to seek recourse to procedures which Congress intended to be available under the act. ${ }^{72}$ It seems unfortunate that Congress is so much less diligent in providing necessary amendments when its enactments seem to be faltering, than is the Court in providing the patchwork necessary to support its past decisions.

71. In 1953, for example, the twenty-five largest producers owned almost one-half of all reserves, while the five largest owned one-quarter. Neuner, The Natural. Gas INDUSTRY 16 (1960). See also note 25, supra.

72. See the CATCO discussion, supra, and Wisconsin v. FPC, 373 U.S. 294 (1963). 